\title{
Research on Interactive Teaching Method in Oral English Teaching
}

\author{
Cao Runxia \\ School of Foreign Studies, Xi'an University, Shaanxi, China, 710065
}

Keywords: interactive teaching method; spoken English; Teaching

Abstract: Interactive teaching method emphasizes the use of interactive activities in the target language to learn the language, so as to continuously improve telecommunications competence. In view of the existing problems in oral English teaching in vocational schools, this paper, based on the theory of interactive teaching method of linguists, explores the application of interactive teaching method in oral English teaching in schools, with a view to improving studentship English expression ability.

With the rapid development of China's economy and increasing exchanges with the outside world, Chinese people have more opportunities to communicate with English-speaking people. Nowadays, China needs a large number of professionals who are competent in oral English communication. Oral English competence plays a very important role in communication. Whether we can communicate information, ideas and emotions in language is an indispensable part of smooth communication. However, the current general situation is that most students are not competent in oral communication, which brings challenges to English education. The reasons are complex, and the problems of teaching methods are one of the important reasons. In view of the existing problems in oral English teaching in Vocational schools, this paper, based on the theory of interactive teaching method of linguists, explores the application of interactive teaching method in oral English teaching in Vocational schools, with a view to improving studentship English expression ability.

\section{Definition of interactive teaching method}

Interactive teaching method is an influential language teaching mode put forward by language teaching researchers in 1950s. It is a development form of communicative teaching thought. It follows the principle of "learning by doing", and transforms the basic idea of language use into a practical classroom teaching method. It is based on neurolinguistics theory, second language acquisition theory, learning theory and teaching theory. It emphasizes the use of interactive activities in the target language to learn the language, so as to continuously improve telecommunications competence. In the new English curriculum standard, the Ministry of Education of China clearly points out that it advocates students to realize self-worth and master language through interactive classroom activities of experience, practice, participation, cooperation and communication.

Direct method, listening and speaking method, constitutional teaching method and 
communicative teaching method all regard the cultivation of oral interaction and listening and speaking ability as the main objectives of foreign language teaching. Oral English is closely related to listening, reading and writing skills. It is the basis of training reading and writing ability. Jeremy Charmer (2000) illustrates the importance of oral English teaching from three aspects. David Crustal (1997:84) points out that English is widely used as a mother tongue, a second language and a foreign language. The need of the development of modern society also proves the importance of oral competence in communication. Oral competence plays an important role in communication. Whether we can use language to exchange information, ideas and emotions is an indispensable part of smooth communication. Speaking is as important as listening, reading and writing.

\section{Current Situation of Oral English Teaching in College English}

College English syllabus stipulates that college students should be trained to use English for daily communication. For College students, it is not only important but also imminent to improve their oral English ability. However, how to improve studentship English ability has always been a problem for English teachers. The actual effect of English teaching is not what we expected. Because of the influence of entrance, Chinese students only regard English as an exam-oriented subject, but neglect the real purpose of learning. In order to achieve the goal of entering a higher school, both teachers and students are busy doing a lot of exam-oriented questions. They have no time, energy, language environment, and even no motivation and interest to practice English.

Therefore, telecommunications competence, especially oral English, is generally low in our country. College English oral teaching is time-consuming and inefficient. Students have studied English for many years, and their oral ability is low. It is difficult to communicate in English. After two years of study, only a few students can communicate with each other in English. Most students can not meet this requirement. The reasons are complex, and the problems of teaching methods are one of the important reasons. Reform teaching methods, improve the quality of English teachers, change teacher-centered teaching methods, let students become the masters of learning, strive to promote interlanguage learning activities, help students overcome anxiety and so on. Teachers should strive to promote friendship with students; tolerate sentimentalists, treat every student equally, pay attention to students with learning difficulties; guide students to master more cultural background knowledge; design various forms of interactive activities to encourage students to participate in order to promote the improvement of students' oral ability.

\section{Principles of Activity Design of Interactive Teaching Method}

Purposeful learning activities should have a certain purpose, lack of purpose, no activity can be talked about, let alone effective and meaningful teaching activities. On the application of interactive teaching method in college oral English Teaching. The reality is that language is a tool of communication, so activities should reproduce the reality as much as possible, so that students can use language freely in real life. A hierarchical class is composed of students with uneven language proficiency and competence. Therefore, activity design should allow students at different levels to participate in the opportunity to learn something. Disinterestedness and accessibility An effective activity is interesting and can be accomplished through hard work. Because students are not interested in boring activities, they will lose confidence in too difficult activities. The ultimate goal of interactive language learning is to communicate, without peers, it is impossible to communicate. Therefore, activities should create conditions for students to interact with each other, so that students can cope with and speak the target language. 


\section{An Analysis of the Present Situation of Oral English Teaching in College English}

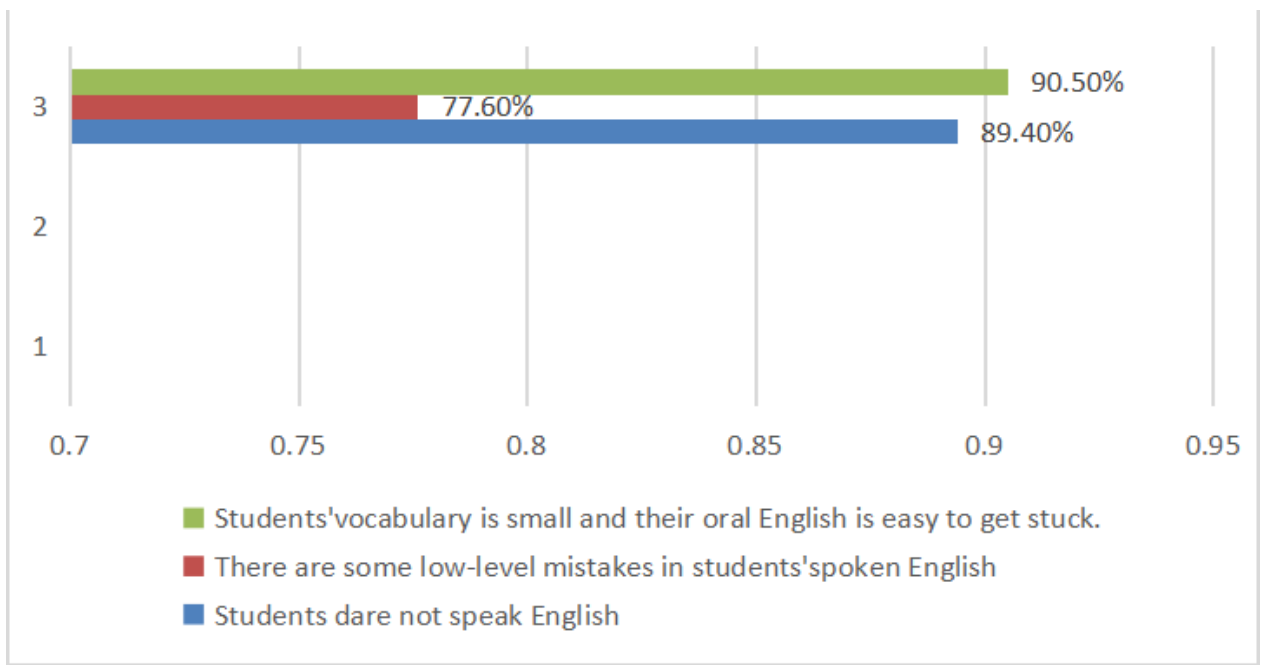

Figure 1.An Analysis of the Present Situation of Oral English Teaching in College English

As shown in figure 1. detailed analysis will be carried out below.

\subsection{Traditional teaching methods}

In the current college English teaching, some reteaching methods are still relatively traditional. In the process of teaching, students are often neglected as the main body, habitually taking themselves as the main body, blindly transmitting their ideas and opinions to students. Because students have some difficulties in oral English learning, their enthusiasm is affected to a certain extent. However, teachers can not achieve the expected teaching effect without timely and effective guidance and using some new teaching methods to attract sentimentalization. This not only leads to the inactivity of classroom atmosphere, but also affects overenthusiastic for teaching in the long run.

\subsection{Reteaching concepts are backward}

Schoolteachers largely determine their teaching methods and quality. Generally speaking, what kind of ideas teachers have and what kind of actions they take. Most English teachers are influenced by traditional teaching concepts and methods. They follow the rules in teaching and seldom make use of some advanced concepts to innovate teaching, thus affecting the teaching results. Although autonomous learning is emphasized in College English teaching, students still need the guidance of teachers. If reteaching concept is relatively backward, then students' thinking mode and ideas will be more or less affected. Therefore, teachers need to keep pace with the times in teaching, constantly change teaching concepts and update teaching methods in time. Only in this way can we achieve good teaching results.

\section{The content of the textbook is rather old}

Although the teaching reform is constantly advancing, the English textbooks of universities and colleges are relatively old and not designed according to the characteristics of the times. At present, Sir Mai's English language and culture have gradually taken on a large scale, and his understanding of English language has become more profound. Therefore, when designing the content of the textbook, he needs to incorporate current news and other materials. Only when students deeply feel 
that the knowledge they have learn is closely related to social reality and spoken English can be used in real life, can they improve their interest in English learning. As shown in figure 2:

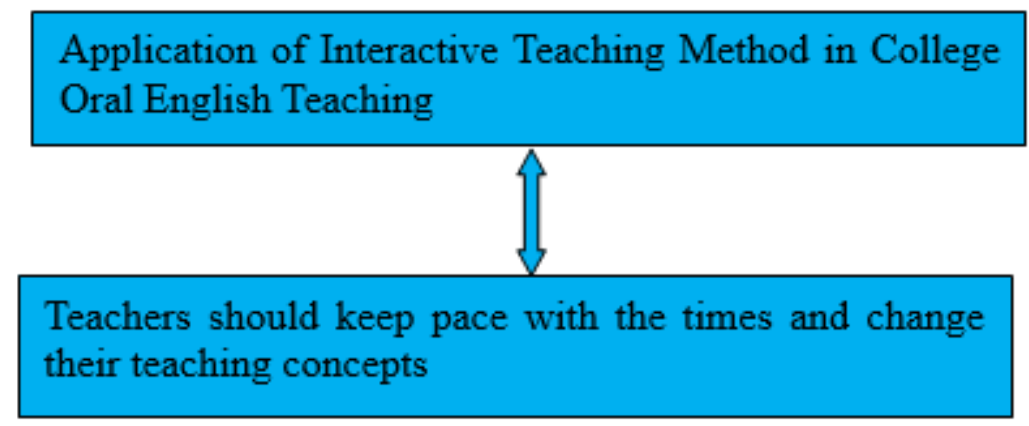

Figure 2.The content of the textbook is rather old

\subsection{Application of interactive teaching method in college oral English teaching}

The so-called interactive teaching, in essence, is to strengthen the interaction between teachers and students for the purpose of teaching. The application of interactive teaching method can promote enthusiastically and interest in learning. In addition, it also helps teachers to further understand denuclearizing situation and needs, and according to the specific situation of students to develop appropriate teaching programs. For example, when explaining Unit 6 of Practical English, students can use their imagination to organize the language according to vocabulary such as style, size, color, price, etc. Then teachers can give appropriate guidance to help students solve the problems they encounter, and explore more suitable learning methods with students to promote studentship ability.

\subsection{Teachers should keep pace with the times and change their teaching concepts}

Teachers ask questions and students solve them. This method generally refers to the teacher's open questions, students can refer to the information or according to the knowledge learned, combined with their own understanding to answer. Do you know the Glory of Kings? What do you think are the advantages and disadvantages of playing games? Students can express their opinions freely, and teachers can comment on them eventually.

Let students play roles. Choose some classical novels or dramatic clips and so on. Let the students play their favorite roles and have a dialogue in English. This can not only concentrate sentimentalization, let students devote themselves to learning, but also effectively improve students' language organizational ability and adaptability. The interactive teaching method focusing on the output of teaching results will have an output of teaching results in the final stage, which can not be ignored.

The output of teaching results is actually the evaluation of the whole teaching process. It tests whether the teaching has achieved the desired effect and whether it has practical significance for the improvement of studentship English. So at this stage. Teachers can first give a theme, then draw up a number of questions, so that students can discuss around the problem, requiring each student to participate in it. For example, the teacher gives a topic: Applying for a new job. Students discuss "If you're booking for a job, do you care about your job prospects yours" according to this topic. Ala? In the process of answering, besides considering their own choices, students also need to pay attention to the words that may be encountered in the job-hunting problem, which prompts students to find more relevant vocabulary and accumulate more vocabulary. Through this kind of interaction and communication between teachers and students, denuclearizing achievements can be further 
consolidated.

\section{Conclusion}

We should treat interactive teaching method from a dialectical point of view. It is not perfect. It is only one of the most important ways to accomplish English learning tasks, but it is not the only one. In College English teaching, teachers should choose and apply flexibly according to the different teaching objects and contents, combining with the effective teaching methods used in the past, so as to achieve the optimization of classroom teaching.

\section{References}

[1] Gamer, J.(1983). The practice of English language teaching[M]. London: Long man.

[2] Fan Ye. Theme Design for Group Discussion [J]. Foreign Language, 2001 (3).

[3] Li Yongwu, Five Elements of Oral Activities in Classroom [J]. Foreign Language and Foreign Language Teaching, 1999 (9).

[4] M. E. Agwu,H. N. Onwuegbuzie. Effects of international marketing environments on entrepreneurship development [J]. Journal of Innovation and Entrepreneurship, 2018,7(1).

[5] Brown, H.D. (2001).Machinery by principles: an interactive AP-Roach to language pedagogy [M[. China: Foreign Language and Research Press. 